The Influence of Managerial Ownership, Board of Commissioners Proportion, Auditing Committee Independence, Sales Growth, Company Size To Return of Equity (ROE) of State Owned Enterprises Which is Listed in The Indonesian Sharia Stock Index 2011-2014 Period

\title{
The Influence of Managerial Ownership, Board of Commissioners Proportion, Auditing Committee Independence, Sales Growth, Company Size To Return of Equity (ROE) of State Owned Enterprises Which is Listed in The Indonesian Sharia Stock Index 2011-2014 Period
}

\author{
Nisful Laila ${ }^{1 *}$, Idzal Dwi Nantyah ${ }^{2}$, and Puji Sucia Sukmaningrum ${ }^{3}$ \\ ${ }^{1}$ Airlangga University, Surabaya, Indonesia
}

\begin{abstract}
The aim of this study was to determine the effect of good corporate governance, growth of sales, and firm size on ROE of State Owned Enterprises which hare listed on the Indonesian Stock Exchange in the 2011-2014 period. The method used is the quantitative method with panel data regression techniques. The data used are secondary data by collecting annual financial data statements of State Owned Enterprises which hare listed on the Indonesian Stock Exchange in the 2011-2014 period.

Panel data regression conduction showed that managerial ownership $\left(X_{1}\right)$ has a negative and significant impact on ROE, the proportion of commissioners has a positive and significant impact on $\operatorname{ROE}\left(X_{2}\right)$, the independence of audit committee $\left(X_{3}\right)$ has a negative and significant impact on $R O E$, growth of sales $\left(X_{4}\right.$ )has a positive and significant impact on $R O E$, firm size $\left(X_{5}\right)$ has a positive and significant impact on ROE as well as managerial ownership, the proportion of commissioners, the independence of audit committee, growth of sales, and firm size simultaneously affect the ROE of State Owned Enterprises in the 2011-2014 period.
\end{abstract}

Keywords: Firm Size, Growth of Sales, Managerial Ownership, Return On Equity (ROE), The Proportion of Board Commissioners, The Independence of Audit Committee

\section{INTRODUCTION}

The high increase of corporate values is a long term goal for companies, in the decision making of investors to companies, it is observed through corporate stock price movement which is transacted in the exchange for companies which already go public. According to Jensen and Meckling (1976) in maximizing corporate value a conflict of interest will appear between managers and stockholders (company owners) which is named the agency problem. Good corporate governance is a corporate need which is closely related to corporate performance. According to the Investment Coordinating Board, observed from experience the United States is the one which has to implement corporate governance restructuration as a cause of the 1929 market crash. A bad corporate governance is also signaled as one of the causes of the Indonesian economic political crisis which began in 1997 and the effect is still felt today. The financial

\footnotetext{
* Corresponding author. Email address: nisful.laila@ feb.unair.ac.id 16
} 
crisis in the United States some time ago is also caused by not applying the GCG principles, several financial scandals such as Enron Corp., Worldcom, Xerox, and others are top executives in the companies where the companies illustrate that the GCG principles are not applied. (Source: www.bpkp.go.id, accessed on September $12015)$.

A chain of corporate failures from giant corporations such as Enron, Tyco, Worldcom, Pharmalat and others has already shaken the belief and trust of shareholders. As a cause, that matter brings attention increase to corporate governance issues. The disclosure of corporate governance implementation in yearly reports is one of the means implemented by companies to increase belief and trust of shareholders especially in transparency. Information about corporate governance is very useful in financial information credibility assessment which is presented in the corporate yearly report. This is related with the disclosure of applying corporate governance so shareholders are able to assess information quality about corporate performance in the future (Bhat and co., 2006). Allah SWT stated in Surah Al-Baqarah: 282:

O Believers! When you enter in the transaction of any debt for a fixed period, then write it down. And a scribe should write between you justly; and the scribe should not refuse to write as he has been taught by Allah, then he should write and let him on whom. The liability falls dictate and fear Allah Who is his Lord and does not leave behind something out of the liability. Then again he on whom liability falls be of low understanding or be weaker be unable to dictate; then let his guardian dictate justly. And make two witnesses from among your men,then if two men be not available then a man and two women such witnesses, as you like, so that either of the two women errs in memory, then the other may remind to that one. And when the witnesses are called, they should not refuse to come. And do not take it as a burden, the liability be it small or big, write it down along with its fixed period. It is more justified in the sight of Allah, in it the evidence will be more suitable and it is nearer to itthat you may not be in doubt; save a ready merchandise which you give or take from hand to hand, there is no sin on you, if you write it not. And when you trade, make witnesses. And neither any scribe be harmed nor the witness (or neither the scribe do harm nor the witness). And if you do such then it would be yours in subordination. And fear Allah and that Allah teaches you and Allah is the all-knowing of everything. Transactions are such as selling and buying, debt, or leasing and the like.

When there is an economic crisis in Indonesia, plans and demands to corporate governance which has been paid less attention as of today increases, many companies public and private fall because of a weak corporate governance. Corporate governance becomes a vital problem for welfare not just the owner, corporate shareholders, but also covers workers and people in society as a whole. In Indonesia corporate governance truly becomes the center of attention since Indonesia experienced an economic crisis mid-1997.

Some factors which cause the occurrence of an economic crisis according to Harahap (2003) which is quoted by Lastanti (2004), there are two aspects which are internal and external aspects. The internal aspect covers all fundamental economic problems of each country, while the external aspect covers the lack of supervision of traditional banking institution practices and less precise investment decisions. Corporate governance or corporate management is a control mechanism for managing and processing businesses with the means for increasing ability and 
The Influence of Managerial Ownership, Board of Commissioners Proportion, Auditing

Committee Independence, Sales Growth, Company Size To Return of Equity (ROE) of State

Owned Enterprises Which is Listed in The Indonesian Sharia Stock Index 2011-2014 Period

accountability of companies for considering the interests of parties which are related to the company (stakeholders), not only the shareholders. With a good company management the company's value will increase among them is the company's financial performance especially for corporate return of equity (ROE).

According to Made (2011) ROE shows corporate ability for producing profit after tax by using their own capital and this ratio is very important to the shareholder party for knowing effectiveness and efficiency of capital processing implemented by corporate management, then a good corporate governance is also able to decrease harmful risks as a cause of developer action which tends to benefit themselves and increase company stock prices in the long term such as the research implemented by McKinsey (2002) which stated that $51 \%$ of investors demand transparency as a reference in implementing corporate stock purchase by institutional investors. In other words corporate governance will create a good corporate performance and increase investor trust to corporate performance.

In facing global competition every company is demanded to anticipate the rivalry which occurs between every company, so companies implement economic activities and manage functions in companies effectively and efficiently. In this matter the finance management has an interest with how to create and maintain economic value or wealth, so in decision making there is a purpose for maximizing profit, prospering company owners or shareholders and maintaining the survivability of the company and developing the business to reach the goal. Murni and Andriana (2007) stated, the approach of corporate growth is a component for assessing corporate prospect in the future. It is concluded that corporate growth is a component for assessing corporate prospect in the future and in financial management it is measured based on total sales alterations. Corporate growth will cause consequences in investment and payment increase.

Brigham and Houston (2006: 39) stated that companies with relatively stable sales are able to be more secure in obtaining more loans and bearing fixed loads which are higher compared with companies with unstable sales. This has to be supported with enough capital for fulfilling the company's needs for increasing company sales. Companies which grow rapidly will possibly choose to use external funds such as banks, capital market, and suppliers to fulfill capital compared with companies with slow sales growth.

With the company entering the capital market, it can be said that the company desires to develop and compete globally, because of confidence in having a needed competitive advantage to still compete in the global market (Bawden, 1992; and Glancy, 1996). The expansion is also meant for obtaining economies of scale. The economies of scale of a company is reflected with production cost decrease (input) in line with the total production (output). If this economy of scale is reached, the companies which are diversified (diversified firms) have potential to be more profitable than small companies which are specialized (specialized firms).

Schmalensee (1989) found that large companies are more profitable than small companies in the same industry. Like other researchers, Schmalensee uses total assets as a projection of company size, and the measures of accounting profitability levels are represented by profit margin and return on asset. But the previous research implemented by Schmalensee (1987) shows that company size (firm size) and profitability does not relate significantly if companies in one industry are grouped into sub industries. Then the organization theory explains the 
relation between profitability with company size which is attributed with organization transaction cost (Williamson, 1985) Research results of Kumar, Rajan, and Zingales (2001) showed that company size increases if law institutions increase protection to the resources of the company. The critical resources theory also indicates that the larger the company scale the profitability will also increase, but in a certain point or number company size will decrease company profit. Based on the explanations above the researcher intends to research good corporate governance quality (managerial ownership, board of commissioners proportion, auditing committee independence), company size and sales growth partially and simultaneously to the financial ratio variable which is return on equity in State Owned Enterprises which are listed in the Indonesia Sharia Stock Index years 2011-2014.

\section{THEORETICAL BASE AND HYPOTHESIS DEVELOPMENT}

Corporate governance is a concept which is proposed for increasing corporate performance through supervision or monitoring management performance and guaranteeing management accountability to stakeholders by being based on the regulation frame in Indonesia regulated in Act No. 40 year 2007 About Private Companies and Copy of Minister of State Owned Enterprises Regulation Number: PER-01/MBU/2011 ABOUT THE APPLICATION OF GOOD CORPORATE GOVERNANCE IN STATE OWNED ENTERPRISES.

According to the State Development Audit Agency, generally the term good corporate governance is a system of corporate control and regulating which can be observed from the relation mechanism between several parties which manage the company (hard definition) nor observed from values contained in the management mechanism itself (soft definition). The State Development Audit Agency GCG team defines good corporate governance from the soft definition view which is easy to understand by common people which is: "HEALTHY AND ETHICAL COMMITMENT, REGULATIONS, AND BUSINESS IMPLEMENTATION PRACTICE", while the goal of good corporate governance is for creating additional values for all interest parties (stakeholders). As for Good Corporate Governance is proxied with:

1. Managerial Ownership, managerial ownership is an important issue in the agency theory since published by Jensen and Meckling (1976) which stated that the larger the management ownership portion in a company the management will try more active for fulfilling the interests of shareholders which are also themselves.

2. Board of Commissioners Proportion, the board of commissioners' proportion holds an important role in good corporate governance implementation because it is the core of good corporate governance which is tasked for guaranteeing implementation of corporate strategy. For guaranteeing the good corporate governance implementation, board of commissioner members which have integrity, law abiding, and do not have business or other relations with shareholders (majority) are needed directly and indirectly. The board of commissioners is often considered to not provide benefit, this can be seen in the fact that many board of commissioner members do not have the ability and are not able to show their independence. 
The Influence of Managerial Ownership, Board of Commissioners Proportion, Auditing

Committee Independence, Sales Growth, Company Size To Return of Equity (ROE) of State

Owned Enterprises Which is Listed in The Indonesian Sharia Stock Index 2011-2014 Period

3. Auditing Committee, the presence of the auditing committee is regulated through Capital Market Supervisory Agency circular Number SE03/PM/2002, in the implementation the auditing committee has tasks for aiding the board of commissioners for:

3.1 Increasing financial report quality.

3.2 Creating discipline and control which is able to decrease probabilities of the occurrence of violations in company management.

3.3 Increasing effectiveness of auditing internal and external functions.

3.4 Identifying matters which need attention of the board of commissioners.

According to Nalim (2009) good corporate governance is a new name for whichever science or religion including Islamic teachings which have appeared before modern life, yet the value, content, and goal of good corporate governance is already discussed in the Qur'an and Hadith. Although the term good corporate governance is still new, yet the concept is found in Islamic teachings which is in the Qur'an and Hadith:

1. The Qur'an in Surah Al-Baqarah; 282-283, about the gradual transaction process. This verse explains the important meaning of keeping records right so there are no parties who get unfair treatment.

2. Islamic corporate governance which tends to relate every concept and behavior in business management with matters that are transcendental and immanent. This is a consequence from the belief of a Muslim to Allah SWT. So from here we know the tawheed value as a base for all beliefs, thoughts, and behaviors of a Muslim, including in understanding corporate governance. One of the principles which is the largest derivative from the tawheed value is the principle of fair. The principle in good corporate governance is fairness which is meant for presenting a fair company management for all parties. The meaning of fair can be widened in every principle which is in corporate governance and other values which can appear as a cause of fairness implementation. There are some matters which are closely related with the corporate governance principle which are caliphates, accountability, reliability, transparency, and also trustworthiness.

ROE shows the company's ability for producing profit after tax by using its own capital which the company has. This ratio is important for the shareholder party for knowing effectiveness and efficiency of their own capital management which is implemented by the company management. The higher the ratio it means the more efficient the capital use itself which is implemented by the company management party.

The size of the company can be measured by using total assets, sales, or capital of the company. One of the benchmarks which shows the size of the company is the size of assets from the company. Companies which have large total assets shows that the company has reached the mature phase where in this phase the cash flow of the company is already positive and considered to have a good prospect in a relatively long timeframe, other than that it also reflects that the company is relatively more stable and more able to produce profit compared with companies with small total assets (Basuki, 2006). 
Higgins (2003) stated that sales growth comes from two sources which are sales volume increase and price increase. Because all cost variables, the most current assets, and current obligations have tendencies to sales, so it is a good idea for observing growth which is based on company sales. Based on the statement above it is seen that the growth level of a company is able to be observed from volume addition and price increase specifically in sales because sales is an activity which is generally implemented by companies for obtaining a goal which is desired to be reached, which is the expected profit.

\section{Hypothesis}

Based on the literature review above the hypotheses in this research are H1: Managerial Ownership has a partially positive influence to ROE.

H2: Board of Commissioners Proportion has a partially positive influence to ROE. H3: Auditing Committee Independence has a partially positive influence to ROE. H4: Company Size has a partially positive influence to ROE.

H5: Sales Growth has a partially positive influence to ROE.

H6: Managerial Ownership, Board of Commissioners Proportion, Auditing Committee Independence, Company Size, Sales Growth have positive influences simultaneously to ROE.

\section{Analysis Model}

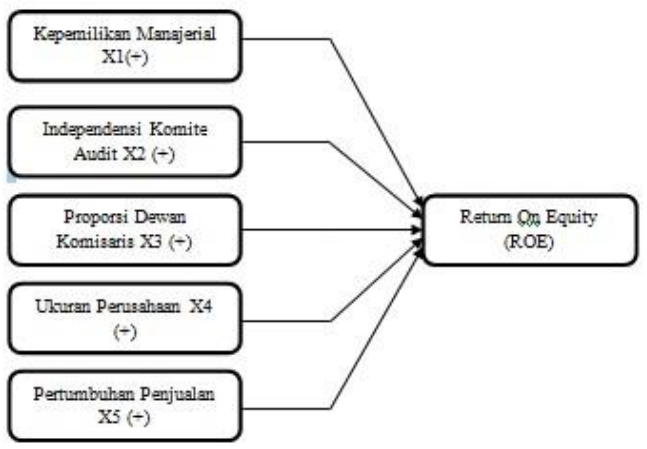

Figure 1 Research Analysis Model

\section{RESEARCH METHOD Research Approach}

The approach used in this research Is the quantitative approach where researched variables are identified for the influence and able to be measured clearly for the relationship between one variable and other variables. This research uses a quantitative approach because research data is in the form of numbers and the analysis uses statistics (Sugiyono,2012;23).

\section{Variable Identification}

Based on the research hypothesis and analysis model, the variables in this research consist of one dependent variable which is ROE (Y) and five independent 
The Influence of Managerial Ownership, Board of Commissioners Proportion, Auditing Committee Independence, Sales Growth, Company Size To Return of Equity (ROE) of State Owned Enterprises Which is Listed in The Indonesian Sharia Stock Index 2011-2014 Period

variables (X) which are, managerial ownership, board of commissioners proportion, auditing committee independence, company size, and sales growth.

\section{Operational Variable Definition}

1. Managerial ownership

Managerial ownership of shareholders and the management party which participates actively in company decision making (Director and Commissioner). Managerial ownership is measured from total share percentage which managers own. (Wahidahwati 2002:5)

2. Auditing committee independence

The committee which is formed by the board of commissioners for helping board of commissioners' tasks in implementing the supervision function to the performance of the board of directors and the management team corresponding with the GCG principles. The measure of the auditing committee independence variable in this research uses a comparative ratio between the independent auditing committee with total auditing committee members (Purwati, 2006 in Manuputty, 2012), so it is formulated:

$$
=\frac{\text { The Independent Auditing Committee }}{\text { total auditing committee members }}
$$

\section{Board of Commissioners Proportion}

The board of commissioners independence is counted by dividing the total independent commissioners' portion to the total commissioners present in the board of commissioners (Haat, et al.2008) so it is formulated as the following:

proportion of total independent board commissioners total number of commissioners present in the board of commissioners

\section{Company Size}

Company size is shown by total assets owned by the company, the larger the company total assets the larger the company size(Murdiyani, 2009).

5. Sales Growth

Swastha and Handoko (2001), growth of sales is an important indicator from market acceptance of a product or service of the company, where income produced from sales will be able to be used for measuring the sales growth level. Sales growth levels are counted with the following equation:

G: Sales growth level

$$
\mathrm{G}=\frac{s 1-s 0}{s 0} \times 100 \%
$$

S1: total sales for the functioning period.

6. ROE (Return On Equity)

$\mathrm{ROE}$ is the return of normal equity

$$
\mathrm{ROE}=\frac{\text { Net Profit }}{\text { Total Equity }}
$$

\section{RESULTS AND DISCUSSION}

The data used passed the classic assumption test. The next step is the chow test for determining whether to use the PLS or FEM model. 
Table 1

Chow Test Output

\begin{tabular}{lrrr}
\hline \hline Effects Test & Statistic & d.f. & Prob. \\
\hline \hline Cross-section $F$ & 6.172059 & $(12,34)$ & 0.0000 \\
Cross-section Chi-square & 60.131225 & 12 & 0.0000 \\
\hline \hline
\end{tabular}

The chow test shows a p-value as large as 0.000 which means significant or less than the significance level used which is $5 \%$. So the model used is the fixed effect model. Next the hausman test needs to be implemented for determining the model used which is the Fixed Effect Model (FEM) or Random Effect Model (REM).

Table 2

\begin{tabular}{lrrr}
\multicolumn{5}{c}{ Hausman Test Output } \\
\hline Test Summary & $\begin{array}{r}\text { Chi-Sq. } \\
\text { Statistic }\end{array}$ & Chi-Sq. d.f. & Prob. \\
\hline \hline Cross-section random & $\mathbf{1 0 . 3 2 2 4 3 2}$ & 5 & 0.0666 \\
\hline \hline
\end{tabular}

Based on test results a P-value of $0.0666>$ alpha 0.05 is obtained so H0 is accepted and the model used is the random effect. Next the $t$ and $f$ tests are implemented, managerial ownership has a significant negative influence to ROE, board of commissioners proportion has a significant negative influence to ROE, auditing committee independence has a significant positive influence to ROE, company size has a positive influence to ROE.

\begin{tabular}{crrrr}
\hline Variable & Coefficient & Std. Error & t-Statistic & Prob. \\
\hline \hline X1? & -0.186048 & 0.042107 & -4.418513 & 0.0001 \\
X2? & 0.335520 & 0.083007 & 4.042051 & 0.0002 \\
X3? & -0.218710 & 0.050173 & -4.359087 & 0.0001 \\
LOG(X4?) & 0.027798 & 0.009095 & 3.056231 & 0.0037 \\
X5? & 0.082302 & 0.022358 & 3.681033 & 0.0006 \\
C & -0.808907 & 0.304729 & -2.654512 & 0.0109
\end{tabular}

Source: Eviews 7

Based on the table above the X1 (Managerial Ownership) significant and negatively influenced variable is obtained with a t-statistic as large as -4.418513 and a p-value as large as 0.0001. The X2 (Auditing Committee Independence) significant and positively influenced variable with a t-statistic as large as 4.042051 and a p-value as large as 0.0002 . Next the X3 (Independent board of commissioners proportion) significant and negatively influenced variable with a t-statistic as large as -4.359087 and a p-value as large as 0.0001 . The $\mathrm{X} 4$ (company size) in the logarithmic function significant and positively influenced variable with a t-statistic as large as 3.056231 and a p-value as large as 0.0037. Lastly the X5 (sales growth) significant and positively influenced variable with a t-statistic as large as 3.681033 and a p-value as large as 0.0006 . 
The Influence of Managerial Ownership, Board of Commissioners Proportion, Auditing Committee Independence, Sales Growth, Company Size To Return of Equity (ROE) of State Owned Enterprises Which is Listed in The Indonesian Sharia Stock Index 2011-2014 Period

Table 3

\begin{tabular}{llll}
\hline \hline R-squared & 0.300534 & Mean dependent var & 0.071744 \\
Adjusted R-squared & 0.224505 & S.D. dependent var & 0.061537 \\
S.E. of regression & 0.054191 & Sum squared resid & 0.135084 \\
F-statistic & 3.952890 & Durbin-Watson stat & 1.787691 \\
Prob(F-statistic) & $\mathbf{0 . 0 0 4 5 8 4}$ & & \\
\hline \hline
\end{tabular}

Source: Eviews 7

Based on the count an F statistic value as large as $3.952890>\mathrm{F}$ table as large as 2.41 with a P-value as large as $0.004584<$ alpha 0.05 so it is rejected and simultaneously there is an influence of managerial ownership, auditing committee independence, independent board of commissioners proportion, company size and $\mathrm{X} 5$ sales growth have influences to the ROE dependent variable. Based on the random effect model above it is known that the $\mathrm{R}$-square value is as large as 0.300534 which means simultaneously the X1, X2, X3, X4, X5 variables have a contribution to explain $\mathrm{Y}$ as large as $30.05 \%$ while the rest are as large as explained by other variables which are not researched or inputted in this research model.

Influence of Managerial Ownership to State Owned Enterprise ROE which are listed in the Indonesia Stock Exchange period 2011-2014

Research results show the X1 (Managerial Ownership) significant and negatively influenced variable with a t-statistic as large as -4.418513 and p-value as large as 0.0001 . Based on that result the $\mathrm{H} 1$ which is proposed in the research is accepted. Yet the negative value in the managerial ownership coefficient has the meaning that the larger the managerial ownership the company ROE decreases. This is also supported by the research of Dwi Sukrini (2011) in her research it is concluded that managerial ownership has a significant negative influence to company value because there are not yet many management parties which have company shares in a significant enough amount. The low number of managerial ownership causes the management party to prioritize their own interests than company interests, the number of share ownership which is not yet significant causes managers to prioritize their goals as managers than shareholders.

Influence of Auditing Committee Independence to State Owned Enterprise ROE which are listed in the Indonesia Stock Exchange period 2011-2014

Research results show the X2 (Auditing Committee Independence) significant and positively influenced variable with a t-statistic as large as 4.042051 and p-value as large as 0.0002. Based on that result the $\mathrm{H} 2$ which is proposed in the research is accepted. This is also supported by research results of Agung Suryana (2003) which implements research about auditing committee, the higher the quality if the auditing committee the better the company profit quality which in the end is able to increase company value. The more independent the auditing committee, there is an increase of supervision in the decision making process which is better, rapidly detects misuse, and effective communication between internal auditing, external auditing and the auditing committee so the company is also audited by public accountants which are independent and produce a good financial report which is able to disclose and inform company activities beginning from planning, funding, credit, and investment and investors are able to assess well about the company's condition for decision making of investment, if there are more 
investors that invest capital in the company that matter also has a positive influence to company financial performance which is return on equity (ROE).

Influence of Board of Commissioners Proportion to State Owned Enterprise ROE which are listed in the Indonesia Stock Exchange period 2011-2014

Research results show the X3 (Board of Commissioners Proportion) significant and positively influenced variable with a t-statistic as large as -4.359087 and p-value as large as 0.0001 . This is in line with the minimum condition of the independent board of commissioners as large as 30 percent which provides enough opportunities for independent commissioners to dominate policies taken by the board of commissioners. If independent commissioners are the majority party $(>50 \%)$ they will be more effective in implementing their roles as company supervisors (Siregar and Utama, 2005) Sylvia and Siddharta (2005) also stated that the promotion of an independent board of commissioners by the company might only be implemented to fulfill regulations but it is not meant to enforce good corporate governance (GCG) in the company, then the research of Charlie Weir et al (2000) Yermarck (1996), Agrawal and Knober (1996) Bhagat and Black in S. Beiner et al (2003) results of the research show that based on data in the field there are still many shareholders that have dual positions as board of commissioner members. An independent board of commissioners generally has a better supervision to management, so decreases the chances of fraud in presenting financial reports implemented by managers (Chtourou et al., 2001) or in other words the more competent the board of commissioners the less the chances of fraud in financial reports.

Influence of Company Size to State Owned Enterprise ROE which are listed in the Indonesia Stock Exchange period 2011-2014

Research results show the X4 (Company Size) in logarithmic function significant and positively influenced variable with a t-statistic as large as 3.056231 and p-value as large as 0.0006. The objects in this research are State Owned Enterprises which are large companies with large total assets in line with the research of Basuki (2006) companies which have large total assets show that the company has reached maturity where in this phase the company cash flow is already positive and considered to have a good prospect in a relatively long time period and relatively stable and more capable of producing profit.

Influence of Sales Growth to State Owned Enterprise ROE which are listed in the Indonesia Stock Exchange period 2011-2014

Research results show the X5 (Sales Growth) significant and positively influenced variable with a t-statistic as large as 3.681033 and p-value as large as 0.0006. Based on the research results the higher the sales growth the profit produced by the company will be more efficient so the ROE value will also increase, so the sales growth variable has a positive influence to ROE in this research. This is in line with the research of Sugihen (2003) sales growth has a positive influence to financial performance measured from profitability. 
The Influence of Managerial Ownership, Board of Commissioners Proportion, Auditing

Committee Independence, Sales Growth, Company Size To Return of Equity (ROE) of State

Owned Enterprises Which is Listed in The Indonesian Sharia Stock Index 2011-2014 Period

\section{CONCLUSION}

1. Managerial ownership and board of commissioners proportion have negative and significant influences to the return on equity of State Owned Enterprises which are listed in the Indonesia Stock Exchange period 20112014. For companies it is expected that the implementation and application of good corporate governance is implemented well not only as mere formality so that matter is able to provide benefit not only to company reputation but also to stakeholders, shareholders, and society.

2. Auditing committee independence, company size, and sales growth have positive and significant influences to the return on equity of State Owned Enterprises which are listed in the Indonesia Stock Exchange period 20112014.

\section{References}

Act No.40 Year 2007 About Private Companies and Copy of Minister of State Owned Enterprises Regulation Number : PER - 01/MBU/2011 ABOUT THE APPLICATION OF GOOD CORPORATE GOVERNANCE IN STATE OWNED ENTERPRISES.

Act Number 19 Year 2003 About State Owned Enterprises.

Alnasser, S. A. S., \& Muhammed, J. (2012). Introduction to Corporate Governance From Islamic Prespective. Journal Humanomics, 28(3).

Al-Quran.

Andrei, S., \& Vishny, R. W. (1997). A Survey of Corporate Governance. The Journal Of Finance, LII(2).

Anshori, M., \& Iswati, S. (2009). Buku Ajar Metodoloogi Penelitian Kuantitatif. Surabaya: Airlangga University Press.

State Development Audit Agency. Jakarta (www.bpkp.go.id)

Baltagi, B. H. (2005). Econometric Analysis of Panel Data. $3^{\text {rd }}$ ed. Chichester: John. Wiley \& Sons Ltd.

Bawden, W. J. (1992). The Global Risks and Rewards for US Insurers. Price Waterhouse Review, 36(2), 38-45.

Beiner, S, et al. (2003). Is Board Size an Independent Corporate Governance Mechanism?. Working Paper.

Bhagat, S., \& Bolton, B. (2008). Corporate Governance and Firm Performance. Journal of Corporate Finance.

Bodie., Kane., \& Marcus. (2014). Manajemen Portofolio dan Investasi. Jakarta: Salemba Empat. 
Brigham, H. (2006). Dasar-Dasar Manajemen Keuangan. Jakarta: Salemba Empat.

Bungin, M. B. (2005). Metodologi Penelitian Kuantitatif. Jakarta: Kencana.

Bursa Efek Indonesia. Jakarta. (www.idx.co.id)

Capital Market Supervisory Agency and Financial Institution Circular Number SE03/PM/2002

Circular SE-14/MBU/2010 Pasal 2 ayat 1 KEP 117/MBU/2002 revised PERMEN $1 / 2011$ article 44 clause 1 .

Chapra, M. U., \& Ahmed, H. (2008). “Corporate Governance Lembaga Keuangan Syariah”. Jakarta: Bumi Aksara.

Chtorou, et al. (2001). Corporate Governance and Earnings Management. Social Science Research Network.

Decree of the Minister of State Owned Enterprises Number Kep-117/MMBU/2002.

Forum Corporate Governance Index (FCGI). Jakarta (www.fcgi.or.id)

Foss, N. (1993). Theories of the firm: Contractual and competence perspectives. Journal of Evolutionary Economics, 22, 479-495.

Gauri, B., Hope, O., \& Kang, T. (2006). Does Corporate Governance Transparency Affect The Accuracy of Analyst Forecast. Journal Accounting and Finance, 46.

Ghozali, I. (2005). Aplikasi Analisis Multivariate Dengan Program SPSS. Semarang: BP Undip.

Ghozali, I. (2006). Aplikasi Analisis Multivariat dengan Program SPSS. Cetakan Keempat. Semarang : Badan Penerbit Universitas Diponegoro.

Glancy, S. (1996). Trends in Word Insurance: A World Wide Study Based on the 1994 Vintage Annual Reports of 100 Major Insurers. Dublin: Lafferty Publications.

Grossman, S., \& Hart, O. (1986). The costs and the benefits of ownership: A theory of vertical integration. Journal of Political Economy, 619-719.

Gujarati, D. (1998). Ekonometrika Dasar. Jakarta: Erlangga

Hall, M., \& Weiss, L. (1967). Firm size and profitability. The Review of Economics and Statistics, 49, 319-331.

Higgins. (2003). Transfer of Value From Fit. Journal of Personality and Social Psychology, 84, 1140-1153.

Horne, J. C. V., \& Wachowicz, J.M. Jr. (2013). Prinsip-Prinsip Manajemen Keuangan. Jakarta: Salemba Empat. 
The Influence of Managerial Ownership, Board of Commissioners Proportion, Auditing

Committee Independence, Sales Growth, Company Size To Return of Equity (ROE) of State

Owned Enterprises Which is Listed in The Indonesian Sharia Stock Index 2011-2014 Period

Husnan, S. (2009). Dasar-Dasar Teori Portofolio \& Analisis Sekuritas. Yogyakarta: Unit Penerbit dan Percetakan STIM YKPN.

Ikatan Akuntan Indonesia. Jakarta (www.iaiglobal.or.id)

Jati, F. (2009). Pengaruh Struktur Good Corporate Governance terhadap Kinerja Perusahaan Manufaktur yang terdaftar di Bursa Efek Indonesia. Journal Accounting Universitas Gunadarma.

Jensen, M., \& Meckling, W. (1976). Theory of the firm: Managerial behavior, agency costs and capital structure. Journal of Financial Economics, 3, 305360 .

Karim, A. A. (2010). Bank Islam: Analisis Fiqh dan Keuangan. Jakarta: Raja Grafindo Persada

Kasim, N., Htay, S. N. N., \& Salman, S. A. (2013). Conceptual Framework for Shari'ah Corporate Governance with Special Focus on Islamic Capital Market in Malaysia. International Journal of Trade Economics and Finance, 4(5).

Kasmir. (2008). Analisis Laporan Keuangan. Jakarta: Rajawali Pers.

Kinsey, Mc. (2002). Presepective on Corporate Finance and Strategy. Mc Kinsey Company.

Kumar, K. B., \& Rajan, R.G., \& Zingales, L. (2001). What determines firm size?, Working paper, University of Chicago.

Lastanti, H. S. (2004). Hubungan Corporate Governance dengan Kinerja Perusahaan dan Reaksi Pasar. Konferensi Nasional Akuntansi.

Manuputty, G. G. (2012). Pengaruh Karakteristik Komite Audit Terhadap Perusahaanfyang Mengalami Kesulitan Keuangan (Financial Distress) dan Tidak Mengalami Kesulitan Keuangan (Non Financial Distress). [Thesis]. Semarang: Fakultas Ekonomika dan Bisnis Universitas Diponegoro.

Murdiyani. (2009). Pengaruh Informasi Prospektus Perusahaan Terhadap Initial Return Pada Penawaran Saham Perdana (Studi Pada Perusahaan LQ-45 2001-2008). [Thesis]. Semarang: Faculty of Economics and Business, Diponegoro University.

Murni, S., \&Andriana. (2007). Pengaruh Insider Ownership, Institusional Investor, Dividen Payments, dan Firm Growth terhadap Kebijakan Hutang Perusahaan. Business Accounting Journal, (7)1, 15-24.

Nalim. (2009). Good Corporate Governance Dalam Perspektif Islam. Jurnal Hukum Islam, 12(1). STAIN Pekalongan.

Otoritas Jasa Keuangan. Jakarta. (www.ojk.go.id) 
Peraturan Menteri Perdagangan Republik Indonesia N0.46/M-DAG/PER/9/2009 tentang Penerbitan Surat Izin Usaha Perdagangan Pasal 3.

Philip, K. (2000). Manajemen Pemasaran. Jakart: PT Prenhallindo.

Prasetya, P. L. (2013). Pengaruh Good Corporate Governance terhadap Kinerja Perusahaan (Studi Empiris pada Perusahaan Jasa Non Keuangan yang terdaftar di Bursa Efek Indonesia Tahun 2009-2011). [Thesis]. Semarang: Diponegoro University.

Rajan, R., \& Zingales, L. (2001). The firm as a dedicated hierarchy: A theory of the origins and growth of firms. Quarterly Journal of Economics.

Republic of Indonesia Department of Religion. (2010). Al-Quran Tajwid dan Terjemahan. West Java: CV Penerbit Diponegoro.

Saputro, B. R. (2006). Analisis Perbedaan Harga dan Volume Saham Sebelum dan Sesudah Pengumuman Indonesia Sustainability Reporting Award (ISRA) 2005.

Schmalensee, R. (1989). Intra-Industry profitability differences in US manufacturing: 1953- 1983. Journal of Industrial Economics, 37, 337-357.

Schmalessee, R. (1987). Collusion versus differential efficiency: Testing alternative hypothesis. Journal of Industrial Economics, 35, 399-425.

Siregar, S. V., \& Utama, S. (2005). Pengaruh Struktur Kepemilikan, Ukuran Perusahaan,dan Praktek Corporate Governance Terhadap Pengelolaan Laba (Earnings Management). SNA VIII Solo, 15 - 16 September 2005.

Solomon, J., \& Solomon, A. (2004). Corporate Governance and Accountability. England: Jhon Wiley \& Sons, Ltd.

Suaryana, A. (2003). Pengaruh Komite Audit terhadap Kualitas Laba. Simposium Nasional Akuntansi Solo Tanggal 15-16 September 2005.

Sudana, I. M. (2011). Manajemen Keuangan Perusahaan Teori \& Praktik. Jakarta: Erlangga.

Sugihen, S. G. (2003). Pengaruh Struktur Modal terhadap Produktivitas Aktiva, Kinerja Keuangan, serta Nilai Perusahaan Industri Manufaktur Terbuka di Indonesia. [Disertasi]. Surabaya: Universitas Airlangga.

Sugiyono. (2012). Metode Penelitian Kuantitatif, Kualitatif, dan $R \& D$. Cetakan ke-17. Bandung: CV. Alfabeta.

Sukrini, D. (2011). Kepemilikan Manajerial, Kepemilikan Institusional, Kebijakan Dividen, dan Kebijakan Hutang Analisis terhadap Nilai Perusahaan. Accounting Analysis Journal, 1(2).

Sulaiman, M., Majid, N. A., \& Arifin, N. M. (2011). Corporate Governance of Islamic Financial Institutions in Malaysia. $8^{\text {th }}$ International Conference on Islamic Economics and Finance. 
The Influence of Managerial Ownership, Board of Commissioners Proportion, Auditing

Committee Independence, Sales Growth, Company Size To Return of Equity (ROE) of State

Owned Enterprises Which is Listed in The Indonesian Sharia Stock Index 2011-2014 Period

Sunarto., Budi, A. P. (2009). Pengaruh Leverage, Ukuran, dan Pertumbuhan Perusahaan terhadap Profitabilitas. Telaah Manajemen, 6(1).

Swastha, B., \& Handoko, H. (2011). Manajemen Pemasaran-Analisis Perilaku Konsumen. Yogyakarta: BPFE.

Sylvia, et al. Pengaruh Struktur Kepemilikan, Ukuran perusahaan, dan Praktik Corporate Governance terhadap Pengelolaan Laba (Earnings Management.) Simposium Nasional Akuntansi (VIII) Solo.

Tandelilin, E. (2010). Portofolio dan Investasi Teori dan Aplikasi. Yogyakarta: Kanisius.

Tjondro, D., \& Wilopo, R. (2011). Pengaruh Good Corporate Governance (GCG) terhadap Profitabilitas dan Kinerja Saham Perusahaan Perbankan yang tercatat di Bursa Efek Indonesia. Journal of Business and Banking, 1(1).

Wahidahwati. (2002). Pengaruh Kepemilikan Manajerial dan Kepemilikan Institusional Pada Kebijakan Hutang Perusahaan : Sebuah Perspektif Theory Agency. The Indonesian Journal of Accounting Research, 5(1).

Williamson, O. E. (1985). The Economic Institutions of Capitalism. Economics Discussion Papers.

World Bank Group. Mekanisme Penerapan Good Corporate Governance. (online article). (www.worldbank.org.) Accessed on october 242015. 